\title{
Referendum lokalne w sprawie utworzenia, połączenia, podziału i zniesienia gminy oraz ustalenia granic gminy - wybrane aspekty
}

Streszczenie: W opracowaniu zostały omówione wybrane aspekty prawne udziału mieszkańców w procedurze ustalania i zmian granic gmin, w szczególności prawna regulacja mechanizmu przeprowadzania referendum lokalnego $\mathrm{z}$ inicjatywy mieszkańców w sprawie utworzenia, połączenia, podziału i zniesienia gminy oraz ustalenia granic gminy. Autorka wyeksponowała różnice i sposób ukształtowania relacji między instytucją referendum lokalnego w sprawie utworzenia, połączenia, podziału i zniesienia gminy oraz ustalenia granic gminy a instytucją konsultacji z mieszkańcami. Przedmiotem rozważań stały się także budzące wątpliwości zagadnienia proceduralne dotyczące przeprowadzenia przedmiotowego referendum takie, jak warunki skutecznego złożenia wniosku w sprawie przeprowadzenia referendum, ocena złożonego wniosku, charakteru wyników tego referendum, sposób oraz katalog związanych z tymi wynikami podmiotów. Ponadto przedstawiono najważniejsze ustalenia, które poczyniły na tym tle sądy administracyjne.

Słowa kluczowe: referendum lokalne, zmiany granic gmin

$\mathbf{Z}$ miany o charakterze demograficznym, kwestie ekonomiczne, zmiany charakterze społecznym związane $\mathrm{z}$ funkcjonowaniem społeczności wielkomiejskich i tzw. społeczności bezlokalnych oraz partykularne dążenia do ekspansji terytorialnej i przez to poprawy jakości funkcjonowania określonych społeczności, także kosztem formalnej likwidacji innych, mniejszych społeczności - to wszystko powoduje, że na nowo odżywa dyskusja dotycząca tworzenia, łączenia, podziału, znoszenia oraz ustalania granic gmin. Dyskusja ta prowadzona jest w wielu płaszczyznach, w tym w płaszczyźnie prawnej, a jednym z jej doniosłych aspektów są mechanizmy partycypacji społecznej w procedurze ustalenia i zmiany granic gmin. Podstaw prawnych dla tej dyskusji należy poszukiwać przede wszystkim w konstytucyjnym określeniu przesłanek kształtowania podziału terytorialnego państwa, tj. art. 15 ust. 2 Konstytucji Rzeczypospolitej Polskiej (Konstytucja Rzeczypospolitej Polskiej), zasadzie 
ochrony granic społeczności lokalnych, wyrażonej w art. 5 Europejskiej Karty Samorządu Lokalnego (Europejska Karta Samorzq̨u Lokalnego) oraz regulacjach ustawy z dnia 8 marca 1990 r. o samorządzie gminnym ${ }^{1}$ (Ustawa o samorzadzie gminnym), które kreują model tworzenia, łączenia, dzielenia, znoszenia gmin oraz ustalania ich granic. Ustawodawca przewiduje dwie formy udziału mieszkańców w tej procedurze: referendum lokalne i konsultacje z mieszkańcami.

Instytucja referendum lokalnego w sprawie utworzenia, połączenia, podziału i zniesienia gminy oraz ustalenia granic gminy została wprowadzona do u.s.g. na mocy postanowień ustawy z dnia 26 maja $2011 \mathrm{r}$. o zmianie ustawy o samorządzie gminnym oraz niektórych innych ustaw (Ustawa o zmianie ustawy).

Uchwalając tę ustawę ustawodawca zakończył - jak początkowo mogłoby się wydawać - znamienną dyskusję toczoną w literaturze przedmiotu (zob. Feja-Paszkiewicz, 2010, s. 35 i n.; Uziębło, 2008, s. 18 i n.; Kisielewicz, 2007, s. 44 i n.; Feja-Paszkiewicz, 2004, s. 55 i n.; Banaszak, 2003, s. 73, Kręcisz, Taras, 2003, s. 85 i n.), która finał znalazła przed Trybunałem Konstytucyjnym (Wyrok Trybunału Konstytucyjnego z dnia 26 lutego 2003 r.), czy w sprawie utworzenia, połączenia, podziału i zniesienia oraz ustalenia granic gminy dopuszczalne jest przeprowadzenie referendum lokalnego, którego zasady i tryb przeprowadzania określa ustawa z dnia 15 września 2000 r. o referendum lokalnym² (Ustawa o referendum lokalnym). W istocie przedmiotową regulacją rozwiązano jedynie część $\mathrm{z}$ istniejących w tym obszarze wątpliwości. Zmiana prawa spowodowała, bowiem pojawienie się nowych zagadnień, wśród których do kluczowych należą kwestie relacji, które zachodzą miedzy instytucją konsultacji z mieszkańcami w sprawie ustalenia i zmiany granic gminy a instytucją referendum lokalnego, kryteriów oceny dopuszczalności przeprowadzenia takiego referendum, charakteru wyników tego referendum, sposobu oraz katalogu związanych tymi wynikami podmiotów.

Artykuł 4c ust. 1 i 2 u.s.g. stanowi, iż w sprawie utworzenia, połączenia, podziału i zniesienia gminy oraz ustalenia granic gminy, które zbiorczo można określić jako ustalenie i zmianę granic gminy (FejaPaszkiewicz, 2010, s. 28-30), może być przeprowadzone referendum lokalne z inicjatywy mieszkańców oraz, że z inicjatywą przeprowadzenia tego referendum wystapić może jedynie grupa co najmniej 15 obywateli,

\footnotetext{
1 Dalej: u.s.g.

${ }^{2}$ Dalej: u.r.l.
} 
o której mowa w art. 11 ust. 1a u.r.l. Z regulacją u.s.g. skorelowany jest art. 11 ust. 1a u.r.l. zgodnie, z którym $\mathrm{z}$ inicjatywą przeprowadzenia referendum na wniosek mieszkańców gminy w sprawie utworzenia, połączenia, podziału i zniesienia gminy oraz ustalenia granic gminy wystapić może jedynie grupa co najmniej 15 obywateli, którym przysługuje prawo wybierania do rady gminy. Ustawodawca przesądził, zatem, że przedmiotowe referendum ma charakter fakultatywny oraz „oddolny”, bo z inicjatywą jego przeprowadzenia mogą wystapić tylko mieszkańcy. Nie mogą tego uczynić organ stanowiący gminy, statutowa struktura terenowa partii politycznej działająca w danej jednostce samorządu terytorialnego i organizacja społeczna posiadająca osobowość prawną, której statutowym terenem działania jest co najmniej obszar danej jednostki samorządu terytorialnego, tj. podmioty wskazane $\mathrm{w}$ art. 11 ust. 1 u.r.l.

W art. 4c ust. 3 i 4 u.s.g. wskazano okoliczności kategorycznie wykluczające przeprowadzenie referendum lokalnego w sprawie ustalenia i zmiany granic gminy, tzn. referendum nie przeprowadza się, jeżeli z analizy przeprowadzonej przed referendum wynika, że na skutek podziału lub ustalenia nowych granic gminy: 1) dochody podatkowe na mieszkańca gminy w zmienionych granicach lub gminy utworzonej byłyby niższe od najniższych dochodów podatkowych na mieszkańca ustalonych dla poszczególnych gmin zgodnie z ustawą z dnia 13 listopada $2003 \mathrm{r}$. o dochodach jednostek samorządu terytorialnego (Ustawa o dochodach jednostek), 2) gmina w zmienionych granicach lub gmina utworzona byłaby mniejsza od najmniejszej pod względem liczby mieszkańców gminy w Polsce według stanu na dzień 31 grudnia roku poprzedzającego ogłoszenie rozporządzenia, o którym mowa w art. 4 u.s.g. Analizy w tym zakresie dokonuje właściwy wojewoda.

Wskazana regulacja koresponduje $\mathrm{z}$ art. 4d u.s.g., który formułuje pod adresem Rady Ministrów dokładnie takie same negatywne przesłanki dokonywania ustalenia i zmiany granic gmin (chodzi tu o identyczne, jak powołane wyżej wskaźniki ekonomiczne i demograficzne). Kategoryczne stwierdzenie zawarte $w$ tym artykule, iż Rada Ministrów nie przeprowadza zmian, o których mowa w art. 4 ust. 1 pkt 1 u.s.g. powoduje, że przeprowadzenie referendum lokalnego byłoby niecelowe, skoro i tak wiadomo, że Rada Ministrów nie wprowadzi przedmiotowych zmian. W takim przypadku niecelowe, ale nie zakazane prawem - w przeciwieństwie do referendum lokalnego - jest także przeprowadzenie konsultacji z mieszkańcami, bowiem Rada Ministrów, także wówczas nie ma możliwości wprowadzenia przedmiotowych zmian. Chcę podkreślić, iż zakaz 
wprowadzony na mocy art. 4d u.s.g. odnosi się do wszelkich zmian granic gmin dokonywanych przez Radę Ministrów na podstawie art. 4 ust. 1 pkt 1 u.s.g. tak, by w nowo ustalonych granicach nie powstała gmina - mówiąc najkrócej - biedniejsza i mniej ludna od najbiedniejszej i najmniej ludnej gminy w Polsce.

Na mocy nowelizacji u.s.g. z dnia 26 maja 2011 r. do u.s.g. wprowadzono też postanowienie, że w przypadku przeprowadzania $\mathrm{z}$ inicjatywy mieszkańców przedmiotowego referendum, pytanie zawarte we wniosku o przeprowadzenie referendum, powinno określać szczegółowo proponowane zmiany w podziale terytorialnym państwa oraz, że wojewoda przekazuje ministrowi właściwemu do spraw administracji publicznej informację o publikacji w wojewódzkim dzienniku urzędowym protokołu wyniku referendum w sprawie utworzenia, połączenia, podziału i zniesienia gminy oraz ustalenia granic gminy (art. 4c ust. 5 i 6 u.s.g.).

$\mathrm{Na}$ tle wskazanych regulacji jasne staje się, że referendum lokalne w sprawie utworzenia, połączenia, podziału i zniesienia gminy oraz ustalenia granic gminy i konsultacje z mieszkańcami przewidziane na tle procedury ustalenia i zmiany granic gmin to dwie odrębne instytucje. Świadczy o tym konstrukcja tych instytucji przyjęta przez ustawodawcę. Przepisy u.s.g. dotyczące konsultacji są lakoniczne. Określenie zasad i trybu przeprowadzenia konsultacji z mieszkańcami pozostawiono do określenia lokalnemu prawodawcy (art. 5a ust. 1 i 2 u.s.g.), który wprawdzie musi respektować właśnie te oszczędne postanowienia oraz - jak sądzę - powinien uwzględniać poczynione na ich tle ustalenia organów nadzoru i orzecznictwa, ale zasadniczo regulując te kwestie dysponuje pewnym zakresem swobody. Natomiast instytucja referendum lokalnego została obszernie i szczegółowo uregulowana przez samego ustawodawcę w u.r.1.

Dla relacji, które zachodzą między instytucją konsultacji z mieszkańcami a instytucją referendum lokalnego w sprawie utworzenia, połączenia, podziału i zniesienia gminy oraz ustalenia granic gminy, istotne jest, iż instytucje te są instytucjami alternatywnymi. Zgodnie, bowiem z art. 4a ust. 4 u.s.g.: „W przypadku przeprowadzenia referendum lokalnego w sprawie utworzenia, połączenia, podziału i zniesienia gminy oraz ustalenia granic gminy, o którym mowa w art. 4c, konsultacji z mieszkańcami, o których mowa w ust. 1 i 2 nie przeprowadza się". To powoduje, iż ustalenie i zmianę granic gmin muszą poprzedzić albo konsultacje z mieszkańcami (art. 4a, 4b i 5a u.s.g.), albo referendum lokalne w sprawie utworzenia, połączenia, podziału i zniesienia gminy oraz 
ustalenia granic gminy, przeprowadzane stosownie do postanowień u.r.l., z uwzględnieniem regulacji zawartych w odpowiednich przepisach u.s.g. Takie przynajmniej - moim zdaniem - jest ratio legis, powołanego wyżej art. 4 a ust. 4 u.s.g. Nie sądzę, by zamiarem ustawodawcy było stworzenie sytuacji, w której w tej samej sprawie, tj. utworzenia, połączenia, podziału i zniesienia gminy oraz ustalenia granic gminy, przeprowadzane będą i konsultacje z mieszkańcami, i referendum lokalne, które na poziomie gminy jest referendum gminnym, stosownie do terminologii przyjętej w art. 6 pkt 1 u.r.l.

Jednak u.s.g. nie kształtuje relacji między tymi instytucjami na tyle precyzyjnie, by uniknąć na tym tle konfliktów. W szczególności nie można wykluczyć, iż rada gminy planując zmianę granic gminy postanowi o przeprowadzeniu w tej sprawie konsultacji (stosownie do art. 4a i 4b u.s.g. sama, z własnej inicjatywy ma przecież tylko tę możliwość), a później pojawi się w tej samej sprawie inicjatywa mieszkańców, którzy wystapią z wnioskiem o przeprowadzenie w tej sprawie referendum. Spowoduje to, iż równolegle będą toczyć się czynności wskazane w art. 15 i 16 u.r.l., tzn. przekazanie wniosku wójtowi i sprawdzenie czy wniosek mieszkańców odpowiada przepisom ustawy oraz czynności związane z przygotowaniami do przeprowadzenia w tej sprawie konsultacji, według zasad i trybu określonych w uchwale rady gminy. Dopóki referendum lokalne w sprawie utworzenia, połączenia, podziału i zniesienia gminy oraz ustalenia granic gminy nie zostanie przeprowadzone, przepisy u.s.g. nie wykluczają przeprowadzenia w tej sprawie konsultacji z mieszkańcami. Dopiero „przeprowadzenie referendum lokalnego" w tej sprawie, kategorycznie wyklucza możliwość przeprowadzenia konsultacji z mieszkańcami (art. 4a ust. 4 u.s.g.). Lokalny prawodawca ma oczywiście możliwość uniknięcia tego typu sytuacji, choćby uchylając swoją uchwałę określającą zasady i tryb przeprowadzenia konsultacji z mieszkańcami w sprawie ustalenia i zamiany granic gminy, uzasadniając to właśnie wystapieniem przez grupę uprawnionych mieszkańców z wnioskiem o przeprowadzenie referendum lokalnego w sprawie utworzenia, połączenia, podziału i zniesienia gminy oraz ustalenia granic gminy. Jednak przepisy u.s.g. oraz u.r.l. nie formułują takiego wymogu i nie można wykluczyć, że na tle lokalnych konfliktów ziści się wskazane wyżej niebezpieczeństwo.

O tym, iż zagrożenie to ma charakter realny świadczyć może sytuacja, która miała miejsce w gminie Stepnica (województwo zachodniopomorskie). Konflikt miał tam podobne podłoże, ale dotyczył nadania miejscowości Stepnica statusu miasta, a w odniesieniu do procedury nadania 
gminie lub miejscowości statusu miasta, ustawodawca nadal wprost nie przewidział w przepisach u.s.g. możliwości sięgnięcia do instytucji referendum lokalnego. Dla prowadzonych tu rozważań istotne jest, iż rada gminy w dniu 29 lipca 2011 r. podjęła uchwałę w sprawie przeprowadzenia konsultacji z mieszkańcami Gminy Stepnica w sprawie nadania miejscowości Stepnica statusu miasta. Następnie grupa 15 mieszkańców złożyła wniosek o przeprowadzenie referendum w sprawie nadania miejscowości Stepnica statusu miasta. W efekcie na tej samej sesji rady gminy zostały przedstawione wyniki konsultacji w tej sprawie i równocześnie został rozpatrzony wniosek mieszkańców o przeprowadzenie referendum w tej samej sprawie, a powstały na tym tle konflikt musiał rozstrzygnąc sąd administracyjny (Wyrok WSA w Szczecinie z dnia 6 grudnia 2011 r.).

Jednocześnie, chcę podkreślić, iż konsultacje z mieszkańcami nie straciły swojej uprzywilejowanej „pozycji” w procedurze ustalenia i zmiany granic gmin, bowiem rada gminy sama nie może postanowić o przeprowadzeniu referendum lokalnego w tej sprawie; konieczna jest inicjatywa mieszkańców i dlatego rada gminy planując dokonanie zmian granic gminy nadal jest zobowiązana do przeprowadzenia konsultacji z mieszkańcami. Dopiero skuteczna inicjatywa mieszkańców dotycząca przeprowadzenia referendum lokalnego powoduje, że przeprowadzenie konsultacji nie jest możliwe. W tym kontekście chcę wyraźnie podkreślić, iż na tle obowiązujących przepisów zmianę granic gminy zawsze muszą poprzedzić albo konsultacje z mieszkańcami, przeprowadzane zgodnie z przepisami u.s.g., albo referendum lokalne z inicjatywy mieszkańców, którego zasady i tryb przeprowadzania określają przepisy u.r.l.

Należy zaznaczyć, że charakter prawny wyników konsultacji i referendum jest różny. Wyniki konsultacji z mieszkańcami nie wiążą, w sensie prawnym, rady gminy w przedmiocie wyrażanej przez nią opinii. Natomiast charakter prawny wyników referendum lokalnego jest inny. Zgodnie z art. 55 ust. 1 u.r.l. referendum jest ważne, jeżeli wzięło w nim udział co najmniej 30\% uprawnionych do głosowania, natomiast jego wynik jest rozstrzygający, jeżeli za jednym z rozwiązań w sprawie poddanej pod referendum oddano więcej niż połowę ważnych głosów (art. 56 ust. 1 u.r.1.). Uważam, że postanowienie zawarte w art. 65 u.r.l., zgodnie z którym jeżeli referendum zakończy się wynikiem rozstrzygającym w sprawie poddanej referendum, właściwy organ jednostki samorządu terytorialnego niezwłocznie podejmie czynności w celu jej realizacji, w przypadku referendum lokalnego w sprawie ustalenia i zmiany gra- 
nic gminy należy odczytać w ten sposób, że wynik ważnego referendum, w którym mieszkańcy opowiedzieli się za projektowaną zmianą granic gminy, obliguje zainteresowaną radę gminy do wystapienia z wnioskiem, o którym mowa w art. $4 \mathrm{~b}$ ust. 1 u.s.g., do ministra właściwego do spraw administracji publicznej za pośrednictwem wojewody (w przypadku tzw. trybu wnioskowego zmiany granic gminy).

W tym miejscu pojawia się jednak problem polegający na tym, iż rozporządzenie Rady Ministrów z dnia 9 sierpnia 2001 r. w sprawie trybu postępowania przy składaniu wniosków dotyczących tworzenia, łączenia, dzielenia, znoszenia i ustalania granic gmin, nadawania gminie lub miejscowości statusu miasta, ustalania i zmiany nazw gmin i siedzib ich władz oraz dokumentów wymaganych w tych sprawach ${ }^{3}$ (Rozporządzenie z dnia 9 sierpnia $2001 \mathrm{r}$.), nie dostrzega tego, iż w sprawie ustalenia i zmiany granic gminy może zostać przeprowadzone referendum lokalne. Nawet ostatnia nowelizacja r.s.t.p. dokonana na mocy rozporządzenia Rady Ministrów z dnia 21 maja 2012 r. zmieniającego rozporządzenie w sprawie trybu postępowania przy składaniu wniosków dotyczących tworzenia, łączenia, dzielenia, znoszenia i ustalania granic gmin, nadawania gminie lub miejscowości statusu miasta, ustalania i zmiany nazw gmin i siedzib ich władz oraz dokumentów wymaganych w tych sprawach (Rozporządzenie z dnia 21 maja 2012 r.), wprowadziła jedynie obowiązek ujęcia we wniosku danych poświadczających brak wystąpienia okoliczności wymienionych w art. 4d u.s.g., wraz z uzasadnieniem oraz opinię Głównego Geodety Kraju potwierdzającą przebieg dotychczasowych granic gminy lub gmin objętych wnioskiem z rejestrem granic i powierzchni jednostek zasadniczego podziału terytorialnego kraju. To powoduje, że w przypadku przeprowadzenia ważnego i rozstrzygającego referendum lokalnego w sprawie ustalenia i zmiany granic gminy zainteresowana rada gminy może mieć problem z wystapieniem ze stosownym wnioskiem, skoro powołane rozporządzenie wyraźnie stanowi, iż wniosek powinien zawierać informacje obejmujące m.in. wyniki konsultacji z mieszkańcami w podziale na jednostki pomocnicze gminy uwzględniające liczbę osób uprawnionych do głosowania, liczbę osób, które wzięły udział w konsultacjach oraz liczbę oddanych głosów popierających, przeciwnych i wstrzymujących się oraz do wniosku należy dołączyć m.in. uchwałę wnioskodawcy w sprawie przeprowadzenia konsultacji z mieszkańcami. Oczywiście można argumentować, iż informacje

\footnotetext{
${ }^{3}$ Dalej: r.s.t.p.
} 
dotyczące przeprowadzenia referendum lokalnego i jego wyników (np. uchwała organu stanowiącego w sprawie przeprowadzenia referendum) to przewidziane w $\S 2$ ust. 2 pkt 7 tego rozporządzenia ,inne dokumenty mogące mieć wpływ na rozpatrzenie wniosku". Chcę jednak podkreślić, iż w tym zakresie istnieje luka, która może prowadzić do tego, że wnioski zainteresowanych rad gmin będą znacząco się różnić. Tym bardziej, że propozycja projektodawców zawierała postanowienie, że rozporządzenie Rady Ministrów z dnia 9 sierpnia 2001 r. ma się stosować odpowiednio także $\mathrm{w}$ razie wystapienia $\mathrm{z}$ wnioskiem wskutek przeprowadzenia referendum (Druk sejmowy nr 3408), które jednak nie znalazło się w nowelizacji u.s.g. z dnia 26 maja 2011 r. W kontekście konstytucyjnej zasady legalizmu wyrażonej w art. 7 Konstytucji RP, który stanowi, iż organy władzy publicznej działają na podstawie i w granicach prawa, można zadać pytanie, czy zainteresowane gminy, w ogóle władne są składać wnioski, które nie będą przecież odpowiadać wymogom określonym w r.s.t.p. z 2001 r.?

Ustawodawca nie rozstrzygną jednoznacznie czy referendum w sprawie utworzenia, połączenia, podziału i zniesienia gminy oraz ustalenia granic gminy, które niewątpliwie będzie wykorzystywane w trybie wnioskowym, może znaleźć zastosowanie także w trybie inicjowanym przez Radę Ministrów? Moim zdaniem, ponieważ przepisy u.s.g. nie wprowadzają tu zakazu, można sądzić, iż takie referendum może zostać przeprowadzone także w trybie inicjowanym przez Radę Ministrów. Chodzi tu o sytuację, gdy mieszkańcy gminy dowiedzą się, iż minister właściwy do spraw administracji publicznej wystąpił do rady gminy o opinię, a ta zamierza przeprowadzić wymagane prawem konsultacje. Skuteczne wystąpienie przez mieszkańców do rady gminy z inicjatywą przeprowadzenia referendum $w$ tej sprawie i następnie przeprowadzenie referendum powinno skutkować wyeliminowaniem z tej procedury konsultacji. Pragnę jednak zauważyć, iż problemem w takim przypadku może być dochowanie terminu, który przewidziany jest na wyrażenie opinii przez radę gminy w art. 4a ust. 3 u.s.g. - są to 3 miesiące, a w przypadku niewyrażenia opinii w tym terminie od otrzymania wystąpienia o opinię, wymóg zasięgnięcia opinii uznaje się za spełniony. Dochowanie tego terminu w przypadku gdyby wyrażenie opinii przez radę gminy miało poprzedzić przeprowadzenie referendum z inicjatywy mieszkańców, wydaje się problematyczne.

Pojawia się jeszcze jedno pytanie, czy przedmiotowe referendum może zostać przeprowadzone tylko w gminie zainteresowanej zmiana, 
tj. tej, której organy w trybie wnioskowym występują o korzystną dla siebie zmianę (najczęściej jest to powiększenie terytorium gminy), czy referendum może zostać przeprowadzone także w gminie „objętej wnioskiem", tj. tej, której terytorium planuje się w wyniku zmian zmniejszyć, a nie zachodzą negatywne przesłanki wykluczające przeprowadzenie referendum wskazane $\mathrm{w}$ art. 4c. Niewątpliwie podstawowym mechanizmem w takiej sytuacji jest przeprowadzenie konsultacji z mieszkańcami poprzedzających wydanie opinii przez radę gminy, której terytorium planuje się zmniejszyć, bowiem tylko o przeprowadzeniu konsultacji, zgodnie z przepisami u.s.g., może postanowić samodzielnie rada gminy. Co jednak, jeśli w tej sytuacji mieszkańcy gminy objętej wnioskiem wystąpią do rady gminy o przeprowadzenie przedmiotowego referendum?

Przepisy u.s.g. nie regulują tej kwestii. Jest jednak zasada wyrażona w art. 32 Konstytucji RP, która nakazuje traktować równo podmioty należące do tej samej kategorii. Skoro mieszkańcy gminy, którzy chcą korzystnych dla siebie rozwiązań i np. powiększenia terytorium swojej gminy, kosztem innej, mogą wypowiedzieć się na ten temat w referendum lokalnym, dlaczego takiej możliwości mieliby być pozbawieni mieszkańcy gminy sąsiedniej, której terytorium planuje się zmniejszyć? W przypadku referendum lokalnego doniosłość ich wypowiedzi jest przecież większa, niż w przypadku konsultacji, bowiem wynik ważnego i rozstrzygającego referendum obliguje radę gminy do podjęcia uchwały o określonej treści. Jeśli mieszkańcy gminy w ważnym i rozstrzygającym referendum lokalnym opowiedzą się za planowaną zmianą granic gminy to rada gminy musi w uchwale wyrazić pozytywną opinię, a jeśli mieszkańcy w referendum opowiedzą się przeciwko zmianie to rada gminy musi w uchwale wyrazić negatywną opinię dla planowanej zmiany granic gmin.

W tym momencie pojawia się jeszcze jedna dyskusyjna kwestia. Można spotkać się z opinią, iż Rada Ministrów wprowadzi zmiany w granicach gminy, które w referendum lokalnym ustalą mieszkańcy (Stojak, 2010, C7). Moim zdaniem takie stanowisko jest błędne. Nie sposób uznać, iż Rada Ministrów jest bezwzględnie zobligowana do dokonania zmian granic gminy stosownie do wyników referendum lokalnego w tej sprawie. Wynik ważnego i rozstrzygającego referendum lokalnego w sprawie utworzenia, połączenia, podziału i zniesienia gminy oraz ustalenia granic gminy, obliguje zainteresowaną radę gminy do wystapienia ze stosownym wnioskiem w sprawie zmiany granic gminy albo do sformułowania opinii o określonej treści (pozytywnej albo negatywnej, tj. aprobującej projektowaną zmianę albo wyrażającą sprzeciw wobec planowanej zmiany granic 
gminy). Przyjęcie, iż istnieje ,automatyzm” wprowadzania zmian przez Radę Ministrów, adekwatnie do wyników referendum przeprowadzonego w jednej z gmin, niewątpliwie stawiałoby gminę objętą wnioskiem (np. tę, której terytorium planuje się zmniejszyć) w niewspółmiernie gorszej sytuacji od gminy wnioskującej o korzystną dla siebie zmianę i przez to naruszało konstytucyjną zasadę równości wyrażoną w art. 32 Konstytucji. Jednocześnie wyłączałoby to możliwość dokonania przez Radę Ministrów oceny spełnienia kryteriów wskazanych w art. 4 ust. 3 u.s.g., według których dokonywane są ustalenie i zmiana granic gmin. Innymi słowy procedura mająca na celu wyważenie interesów skonfliktowanych gmin lub podmiotów (np. w przypadku grupy mieszkańców działających na rzecz utworzenia kolejnej gminy z części terytorium gminy już istniejącej) zamieniałaby się $\mathrm{w}$ procedurę aneksji terytorialnej. W takim przypadku istotne byłoby przecież tylko to, która gmina szybciej przeprowadzi referendum o korzystnym dla siebie wyniku i w ten sposób ,,przejmie” część terytorium innej gminy. Argumentem na rzecz braku ,automatyzmu" po stronie Rady Ministrów, która nie może być bezwzględnie zobligowana do dokonania zmiany granic gmin stosownie do wyniku referendum lokalnego w tej sprawie, może też być fakt, iż w art. 65 u.r.l. stanowi się, że to "właściwy organ jednostki samorządu terytorialnego" - jeżeli referendum zakończy się wynikiem rozstrzygającym w sprawie poddanej referendum - niezwłocznie podejmie czynności w celu jej realizacji, a nie każdy inny organ państwa, w tym Rada Ministrów. Wreszcie, można wskazać, że w tekście nowelizacji u.s.g., która weszła w życie nie znalazła się wcześniej proponowana przez projektodawców zmiana art. 4 ust. 2 u.s.g., zgodnie z którą „Rozporządzenie, o którym mowa w ust. 1 , może być wydane także na wniosek zainteresowanej rady gminy lub w trybie określonym w art. 4c" (Druk sejmowy nr 3408).

Referendum lokalne w sprawie ustalenia i zmiany granic gminy przeprowadzane jest na zasadach i w trybie określonych w u.r.l. Oznacza to, że stosownie do art. 12 ust. 1 i 2 u.r.l. jeszcze przed złożeniem wniosku o przeprowadzenie referendum jego inicjator powiadamia na piśmie wójta (burmistrza, prezydenta miasta) o zamiarze wystąpienia z inicjatywą w tej sprawie. Powiadomienie takie winno zawierać, poza danymi inicjatorów, określenie sprawy, w której ma zostać przeprowadzone referendum. Zgodnie z art. 13 ust. 1 i 2 u.r.l. inicjator referendum, na swój koszt, podaje do wiadomości mieszkańców przedmiot zamierzonego referendum, przy czym w gminie podanie do wiadomości następuje w sposób zwyczajowo przyjęty w danej gminie. Informacja taka powinna 
zawierać pytanie lub pytania referendum albo warianty zaproponowane do wyboru. W przypadku referendum w sprawie ustalenia i zmiany granic gmin należy przyjać, że pytanie powinno określać szczegółowo proponowane zmiany w podziale terytorialnym państwa. Nie można uznać, iż inicjator referendum dopełnił ciążącego na nim obowiązku podania do wiadomości mieszkańców gminy przedmiotu referendum w sytuacji, gdy nie dokonał formalnego, jednoznacznego i skonkretyzowanego ogłoszenia o przedmiocie referendum, np. w prasie codziennej ogólnodostępnej w danej jednostce samorządu terytorialnego lub w inny sposób zwyczajowo przyjęty w danej gminie. Same artykuły prasowe i internetowe omawiające problem, prezentujące stanowiska różnych podmiotów i dokumentujące proces przygotowania do referendum oraz zbierania podpisów nie spełniają tego wymogu (Wyrok Wojewódzkiego Sądu Administracyjnego w Białymstoku z dnia 17 lutego 2015 r., nieprawomocny).

W myśl art. 14 ust. 1 u.r.l., w terminie 60 dni od dnia powiadomienia wójta (burmistrza, prezydenta miasta) o zamiarze wystąpienia z inicjatywą przeprowadzenia referendum jego inicjator zbiera podpisy mieszkańców uprawnionych do wybierania rady gminy, którzy chcą poprzeć inicjatywę w tej sprawie. Podpisy zbiera się na kartach, z których każda ma zawierać informacje o przedmiocie zamierzonego referendum oraz o tym, że poparcia nie można wycofać. Wykluczone jest stosowanie jakichkolwiek nacisków zmierzających do wymuszenia podpisów. Inicjator referendum przekazuje wójtowi pisemny wniosek o przeprowadzenie referendum, który powinien zawierać pytanie lub pytania referendum albo warianty zaproponowane do wyboru (art. 15 ust. 1 i 2 u.r.l.), przy czym w przypadku referendum w sprawie ustalenia i zmiany granic gmin pytanie zawarte we wniosku o przeprowadzenie referendum, powinno określać szczegółowo proponowane zmiany w podziale terytorialnym państwa (art. 4c ust. 5 u.s.g.). Po przekazaniu wniosku o przeprowadzenie referendum wójt przekazuje niezwłocznie wniosek przewodniczącemu organu stanowiącego tej jednostki, a organ stanowiący jednostki samorządu terytorialnego powołuje ze swego składu komisję do sprawdzenia, czy wniosek mieszkańców odpowiada przepisom ustawy (art. 16 ust. 1 i 2 u.r.l.). Z kolei ust. 5 tego artykułu stanowi, że jeżeli komisja stwierdzi, że wniosek o przeprowadzenie referendum zawiera uchybienia, których nie można usunąć, przekazuje wniosek organowi stanowiącemu jednostki samorządu terytorialnego wraz ze swoją opinią.

W tym miejscu warto podnieść, iż rolą komisji, którą ze swojego składu powołuje organ stanowiący jednostki samorządu terytorialnego powo- 
łanej do sprawdzenia, czy wniosek mieszkańców odpowiada przepisom ustawy nie jest ocena celowości wniosku, zasadności zaprezentowanych argumentów lub ,przychylenie się” do stanowiska określonych środowisk, np. grupy mieszkańców popierających wniosek albo mu przeciwnych. Przepisy u.r.l. wskazują, iż komisja bada wyłącznie kwestię, czy wniosek mieszkańców odpowiada przepisom ustawy, a zatem czy odpowiada przepisom u.r.l., tj. czy wystapił z nim uprawniony podmiot i czy podmiot ten dopełnił określonych wymogów (np. sposób podania przedmiotu zamierzonego referendum do wiadomości mieszkańców, liczba podpisów mieszkańców, prawidłowość ich złożenia, dochowanie terminów wskazanych w u.r.l.) i w tym zakresie komisja formułuje swoją opinię. W opinii komisja powinna stwierdzić, że wniosek o przeprowadzenie referendum odpowiada albo nie odpowiada przepisom ustawy. Okolicznością, która spowoduje, że wniosek o przeprowadzenie referendum z inicjatywy mieszkańców, który został złożony zgodnie z przepisami u.r.l. nie doprowadzi do przeprowadzenia referendum jest wynik analizy dokonanej przez właściwego wojewodę w zakresie spełnienia przesłanek wskazanych w art. 4c ust. 3 u.s.g., wskazujący, że na skutek podziału lub ustalenia nowych granic gminy powstanie podmiot, którego dochody podatkowe na mieszkańca gminy w zmienionych granicach lub gminy utworzonej byłyby niższe od najniższych dochodów podatkowych na mieszkańca ustalonych dla poszczególnych gmin zgodnie z ustawą z dnia 13 listopada 2003 r. o dochodach jednostek samorządu terytorialnego (Ustawa o dochodach jednostek) lub gmina w zmienionych granicach lub gmina utworzona byłaby mniejsza od najmniejszej pod względem liczby mieszkańców gminy w Polsce według stanu na dzień 31 grudnia roku poprzedzającego ogłoszenie rozporządzenia Rady Ministrów zmieniającego i ustalającego granice gmin. W takim przypadku, jak już wskazałam, zgodnie z art. 4c ust. 3 u.s.g. referendum lokalnego „nie przeprowadza się" i fakt ten powinien znaleźć odzwierciedlenie w opinii komisji. Nie do przyjęcia jest stanowisko, iż zgodne z przepisami u.r.l. jest przypisanie sobie przez komisję powołaną do sprawdzenia czy wniosek mieszkańców odpowiada przepisom ustawy, prawa do dokonania oceny, że wniosek choć odpowiada przepisom ustawy to powinien zostać odrzucony z powodu jakichś ocennych, pozaprawnych względów takich, jak np. protestów mieszkańców przeciwnych zmianom lub konieczność ochrony innych, partykularnych interesów. W orzecznictwie wyrażono także pogląd, iż komisja powołana do oceny wniosku o przeprowadzenie referendum nie może domniemywać rzeczywistych intencji inicjatora referendum i pod 
tym względem oceniać wniosku, ani też zmieniać sformułowania pytania przedłożonego we wniosku o przeprowadzenie referendum (Wyrok Naczelnego Sądu Administracyjnego z dnia 24 kwietnia 2012 r.).

Kwestią wymagającą wyjaśnienia jest kwestia możliwości podjęcia przez radę gminy uchwały odrzucającej wniosek mieszkańców o przeprowadzenie przedmiotowego referendum. W myśl art. 17 ust. 1 u.s.l. organ stanowiący jednostki samorządu terytorialnego podejmuje uchwałę w sprawie przeprowadzenia referendum, jeżeli wniosek mieszkańców spełnia wymogi ustawy oraz nie prowadzi do rozstrzygnięć sprzecznych z prawem; organ stanowiący jest związany treścią wniosku. Powołany przepis należy rozumieć w ten sposób, iż rada gminy może podjąć uchwałę o przeprowadzeniu referendum z inicjatywy mieszkańców tylko wówczas, gdy zostały spełnione obie te przesłanki, tj. inicjator referendum dopełnił wszystkich wymogów wynikających z u.r.l., co do wystąpienia z wnioskiem oraz referendum nie prowadzi do rozstrzygnięć sprzecznych $\mathrm{z}$ prawem. Brak spełnienia jednej z tych przesłanek daje podstawę do odrzucenia wniosku (Wyrok Wojewódzkiego Sądu Administracyjnego w Krakowie z dnia 4 grudnia 2012 r.). Jednocześnie należy podkreślić, iż ocena rady gminy czy wniosek mieszkańców o przeprowadzenie referendum lokalnego w sprawie ustalenia i zmiany granic gminy nie prowadzi do rozstrzygnięć sprzecznych z prawem, odnosi się do art. 4c ust. 3 u.s.g., tj. wskaźników dotyczących dochodów podatkowych na mieszkańca i liczby mieszkańców gminy w zmienionych granicach lub gminy utworzonej. Na ocenę tę nie składają się elementy pozanormatywne, takie jak np. niechęć włodarzy gminy w aktualnych granicach do ich ewentualnej rewizji. Analogiczne stanowisko wyrażono w orzecznictwie (Wyrok Naczelnego Sądu Administracyjnego z dnia 7 sierpnia 2013 r.; Wyrok Wojewódzkiego Sądu Administracyjnego w Krakowie z dnia 4 grudnia 2012 r.).

Przesłanki wskazane w art. 4 ust. 3 u.s.g. w oparciu, o które dokonywane są ustalenie i zmiana granic gmin, tj. zapewnienie gminie terytorium możliwie jednorodnego ze względu na układ osadniczy i przestrzenny, uwzględniający więzi społeczne, gospodarcze i kulturowe, adresowane są do Rady Ministrów, która jest podmiotem władnym do dokonywania zmian granic gmin. Kompetencji do dokonania samodzielnej oceny czy przesłanki te będzie spełniać gmina w nowych granicach nie posiada rada gminy, której terytorium próbuje się zmienić. Rada gminy nie może, zatem podjąć uchwały odrzucającej wniosek mieszkańców o przeprowadzenie referendum lokalnego w sprawie ustalenia i zmiany granic gminy, 
argumentując, że w ten sposób referendum prowadziłoby do rozstrzygnięć sprzecznych z prawem, bowiem w jej ocenie naruszony zostałby art. 4 ust. 3 u.s.g. Jak przyjął Naczelny Sąd Administracyjny rada gminy nie może „dokonywać oceny wniosku mieszkańców o przeprowadzenie referendum w sprawie podziału Gminy Kamienica, powołując się na przesłanki, które będą przedmiotem badania dopiero na etapie podejmowania przez Radę Ministrów rozstrzygnięcia co do dopuszczalności przeprowadzenia podziału gminy. Odwołanie się, w uzasadnieniu zaskarżonej uchwały, do szkodliwości dla mieszkańców wniosku o przeprowadzenie referendum $\mathrm{z}$ tego powodu, że ewentualne dokonanie podziału gminy doprowadzi do zniszczenia tradycyjnych więzi społecznych, gospodarczych i kulturowych, uznać należy za wykroczenie przez Radę Gminy Kamienica poza kryteria normatywne, w oparciu o które władna ona była dokonać kontroli przedmiotowego wniosku o przeprowadzenie referendum. Ocenę, czy wniosek mieszkańców nie prowadzi do rozstrzygnięć sprzecznych z prawem, należy odnosić do regulacji przepisu art. 4c ust. 3 ustawy o samorządzie gminnym, tj. do dokonywanej przez właściwego wojewodę analizy dotyczącej skutków podziału gminy" (Wyrok Naczelnego Sądu Administracyjnego z dnia 7 sierpnia 2013 r.).

Organ stanowiący jednostki samorządu terytorialnego podejmuje uchwałę w sprawie przeprowadzenia referendum lub uchwałę o odrzuceniu wniosku mieszkańców nie później niż w ciągu 30 dni od dnia przekazania wniosku wójtowi (art. 18 u.r.l.). Uchwała w tej sprawie podlega ogłoszeniu w wojewódzkim dzienniku urzędowym, a w gminie ponadto bezzwłocznemu rozplakatowaniu lub ogłoszeniu w inny sposób zwyczajowo przyjęty $\mathrm{w}$ danej gminie (art. $19 \mathrm{w}$ związku z art. 10 u.r.l.). $\mathrm{Na}$ uchwałę organu stanowiącego jednostki samorządu terytorialnego odrzucającą wniosek mieszkańców w sprawie przeprowadzenia referendum, a także na niedotrzymanie przez ten organ terminu określonego w art. 18 u.r.l., inicjatorowi referendum służy skarga do sądu administracyjnego w terminie 14 dni od dnia doręczenia uchwały lub upływu terminu do jej podjęcia. Sąd administracyjny rozpatruje skargę w terminie 14 dni od dnia jej wniesienia. Skargę kasacyjną wnosi się w terminie 14 dni (art. 20 ust. 1 i 2 u.r.1.). W orzecznictwie wskazuje się, iż w tym przypadku mamy do czynienia z odrębnym trybem wnoszenia skarg, bowiem skargę wnosi się bezpośrednio do sądu administracyjnego. Jest to niewątpliwie przepis o charakterze lex specialis, w stosunku do ogólnych zasad regulujących postępowanie przed sądami administracyjnymi, który ma na celu zagwarantowanie prawidłowej realizacji konstytucyjnie chronionego prawa do 
sądu, wyrażonego w art. 45 ust. 1 Konstytucji. Odrębność trybu i terminu wnoszenia tego rodzaju skarg ma swoje uzasadnienie w funkcji samego wniosku w sprawie referendum, bowiem „Referendum lokalne dotyczyć ma ważnych spraw danej społeczności lokalnej i jakiekolwiek przedłużanie rozpoznawania wniosku o jego przeprowadzenie, także na etapie postępowania przed sądem administracyjnym, nie mieści się w funkcji referendum, jaką jest przyznanie społeczności lokalnej prawa do decydowania o istotnych sprawach lokalnych" (Wyrok Wojewódzkiego Sądu Administracyjnego w Krakowie z dnia 4 grudnia 2012 r.).

Podniesione powyżej zagadnienia to tylko cześć z tych, z którymi stykają się podmioty zaangażowane w procedurę ustalenia i zamiany granic gmin. Jednak wskazują one, że ustawodawca zakończył dyskusję dotycząca referendum lokalnego w sprawie utworzenia, połączenia, podziału i zniesienia gminy oraz ustalenia granic gminy, jedynie w kilku obszarach. W szczególności jednoznacznie przesądził, iż przeprowadzenie takiego referendum jest dopuszczalne, wskazał inicjatora referendum, wymogi, które musi on spełnić oraz negatywne przesłanki wykluczające przeprowadzenie przedmiotowego referendum. W wielu innych obszarach wątpliwości związane z prawnymi aspektami przeprowadzenia referendum lokalnego w sprawie ustalenia i zmiany granic gmin nadal - jak sądzę - będą wymagać ustosunkowania się do nich w literaturze przedmiotu i orzecznictwie. Zmiany w prawie dotyczące regulacji przeprowadzania referendum lokalnego w sprawie ustalenia i zmiany granic gmin, które miały miejsce w 2011 r., oceniam, mimo podniesionych $\mathrm{w}$ artykule niedoskonałości, pozytywnie. Stanowią one krok na rzecz pełniejszego urzeczywistnienia art. 170 Konstytucji, w myśl którego członkowskie wspólnoty samorządowej mogą decydować, w drodze referendum, o sprawach dotyczących tej wspólnoty oraz wzmacniają i rozszerzają mechanizm partycypacji mieszkańców w procedurze ustalenia i zmiany granic gmin.

\section{Bibliografia}

Banaszak B. (2003), Opinia na temat zgodności z Konstytucja RP ustawy z 15 marca 2002 r. o ustroju miasta stołecznego Warszawy, „Samorząd Terytorialny”, $\mathrm{nr} 7-8$.

Druk sejmowy nr 3408, www.sejm.gov.pl.

Feja-Paszkiewicz A. (2004), Konsultacje spoteczne a zasada ochrony granic spoleczności lokalnych, „Przegląd Prawa i Administracji”, t. LXIII. 
Feja-Paszkiewicz A. (2010), Ustalenie i zmiana granic gmin $w$ orzecznictwie Trybunatu Konstytucyjnego - wybrane problemy, „Przegląd Prawa i Administracji”, t. LXXXIII.

Kisielewicz A. (2007), w: K. W. Czaplicki, B. Dauter, A. Kisielewicz, F. Rymarz, Ustawa o referendum lokalnym. Komentarz, Warszawa.

Kręcisz W., Taras W. (2003), Glosa do wyroku Trybunatu Konstytucyjnego z dnia 26 lutego 2003 r., „Przegląd Sejmowy”, nr 3.

Stojak D. (2010), Zmiana granic gminy $w$ drodze referendum. Mieszkańcy sami zadecydujq o podziale terytorialnym kraju, „Rzeczpospolita”, 8-10 października, nr 197.

Uziębło P. (2008), Ustawa o referendum lokalnym. Komentarz, Warszawa.

\section{Akty prawne:}

Europejska karta Samorzadu Lokalnego, Dz. U. 1994, Nr 124, poz. 607, 2006, Nr 154, poz. 1107.

Konstytucja Rzeczypospolitej Polskiej z dnia 2 kwietnia 1997 r., Dz. U. Nr 78, poz. 483 ze zm.

Rozporządzenie Rady Ministrów z dnia 21 maja 2012 r. zmieniajace rozporzqdzenie w sprawie trybu postępowania przy składaniu wniosków dotyczqcych tworzenia, taczenia, dzielenia, znoszenia $i$ ustalania granic gmin, nadawania gminie lub miejscowości statusu miasta, ustalania i zmiany nazw gmin i siedzib ich władz oraz dokumentów wymaganych w tych sprawach, Dz. U. 2012, poz. 644.

Rozporządzenie Rady Ministrów z dnia 9 sierpnia 2001 r. w sprawie trybu postępowania przy składaniu wniosków dotyczqcych tworzenia, łaczenia, dzielenia, znoszenia i ustalania granic gmin, nadawania gminie lub miejscowości statusu miasta, ustalania i zmiany nazw gmin i siedzib ich władz oraz dokumentów wymaganych w tych sprawach, t.j. Dz. U. 2014, poz. 310.

Ustawa z dnia 13 listopada 2003 r. o dochodach jednostek samorzqdu terytorialnego, t.j. Dz. U. 2010, Nr 80, poz. 526 ze zm.

Ustawa z dnia 15 września 2000 r. o referendum lokalnym, t.j. Dz. U. z 2013 r., poz. 706 ze zm.

Ustawa z dnia 26 maja 2011 r. o zmianie ustawy o samorzqdzie gminnym oraz niektórych innych ustaw, Dz. U. Nr 134, poz. 777.

Ustawa z dnia 8 marca 1990 r. o samorzqdzie gminnym, t.j. Dz. U. 2013, poz. 594 ze $\mathrm{zm}$.

\section{Orzecznictwo:}

Wyrok Naczelnego Sądu Administracyjnego z dnia 24 kwietnia 2012 r., sygn. akt II OSK 357/12, http://orzeczenia.nsa.gov.pl.

Wyrok Naczelnego Sądu Administracyjnego z dnia 7 sierpnia 2013 r., sygn. akt II OSK 1371/13, http://orzeczenia.nsa.gov.pl. 
Wyrok Trybunału Konstytucyjnego z dnia 26 lutego 2003 r., sygn. akt K 30/02, OTK ZU A 2003, nr 2, poz. 16.

Wyrok Wojewódzkiego Sądu Administracyjnego w Białymstoku z dnia 17 lutego 2015 r., nieprawomocny, sygn. akt II SA/Bk 1253/14, http://orzeczenia.nsa. gov.pl.

Wyrok Wojewódzkiego Sądu Administracyjnego w Krakowie z dnia 4 grudnia 2012 r., sygn. akt III SA/Kr 1652/12, http://orzeczenia.nsa.gov.pl.

Wyrok Wojewódzkiego Sądu Administracyjnego w Szczecinie z dnia 6 grudnia 2011 r., sygn. akt II SA/Sz 1290/11, http://orzeczenia.nsa.gov.pl.

\title{
Local referendum on the establishment, merger, division and abolition of municipalities and determining the borders of municipalities - selected aspects
}

\begin{abstract}
Summary
This article is intended to discuss selected legal aspects of the participation of citizens in the procedure of the establishment and changing the communes' borders, particularly a legal regulation of the mechanism of holding a local referendum on the citizens' initiative on the creation, connection, division and removing the commune and establishment of the commune's borders. The author has exposed differences and the way of establishing relations between the institution of the local referendum on creation, connection, division and removal of the commune and establishing the commune's borders and the institution of consultations with citizens. The subject of discussion were also procedural issues raising concerns and relating to the conduction of a subjected referendum, such as conditions of an efficient submitting a file on holding a referendum, the assessment of the filed motion, the nature of results of this referendum, the way and catalogue of the entities in these results. Moreover, the most important arrangements which were made in this aspect by administrative courts, have been presented in this article.
\end{abstract}

Key words: local referendum, changing the communes' borders. 
